\title{
Advanced Learner Competence and Relative Clauses in Oral Narratives
}

\author{
Monique Monville-Burston and Maria Kounouni \\ University of Cyprus, Cyprus University of Technology \\ mburston@ucy.ac.cy,maria.kounouni@cut.ac.cy
}

\begin{abstract}
This article examines the use of relative clauses in the oral narratives of advanced Cypriot students of French. The data were collected through storyretelling techniques. Seven native speakers of French and nine non-native Cypriot learners participated in the study. Similarities and differences in the narrative discourse of the two groups were identified. It is shown that two main features characterise narrative competence at advanced level: the use of il $y$ a...qui ('there is someone...who/something...which') presentative constructions and of autonomous relatives. Possible cross-linguistic influence from Greek narrative style on the French oral productions of non-native speakers is also considered.
\end{abstract}

\section{Introduction}

The work presented here is part of a larger project on the acquisition of relativisation by advanced native Greek-speaking learners of French. In previous studies we dealt with the acquisition of relative clauses, of their structure and introductory terms, in students' written productions (Monville-Burston 2008; Monville-Burston \& Kounouni 2008; Monville-Burston \& Kakoyianni-Doa 2009; Monville-Burston \& Kounouni 2010). In this article we concentrate on the advanced learners' use of relative clauses in discourse: what we examine is the nature and functioning of relativised sentences in oral narratives, on the basis of the bilingual 'parallel' corpus collected by Kounouni (Kounouni 2010). Relativisation, as a grammatical/discursive feature, has been singled out by Bartning and her students/collaborators (Bartning \& Kirchmeyer 2003; Bartning \& Schlyter 2004; Hancock 2002; Hancock \& Kirchmeyer 2002; Kirchmeyer 2002) as a marker of advanced non-native speaker (NNS) speech vs. native speaker (NS) speech in French and can thus be regarded as one of the indices of naturalness and fluency in advanced learners-users' speech.

(cc) BY-NC-ND 
The following research questions were addressed:

1) What is the comparative frequency of relative clauses [RCs] in the productions of native speakers' [NS] and non-native speakers' [NNS] speech?

2) Which relative pronouns [RPs] (and which relativised grammatical functions) are used the most by the two groups?

3) What are the informational functions of the RCs used by both groups: identification-referential [restrictives] or predicative-attributive [nonrestrictives]?

4) Where the differences are important between NS and NNS, can crosslinguistic influence be invoked as a possible reason?

First we will describe the study design, we will then give an account of the results obtained, contrasting NS and NNS speech, and in relation to the investigated questions, we will discuss the results, paying particular attention to qui (subject-RP) RCs. Finally in the light of the narrative discourse of Cypriot Greeks we will try to evaluate possible Greek>French interferences in NNS speech.

\section{Methodology and Participants}

The corpus data (gathered in 2010) in the present study come from sixteen subjects, seven native speakers of French (Erasmus exchange students, 3 males, 4 females) and nine Fourth Year and Masters' Cypriot French students (9 females), all at the University of Cyprus. The oral narratives were elicited with the help of three short films shown to the participants on a computer screen, during individual interviews. The films were "silent" cartoons by Mordillo and lasted between 50 and 70 seconds ${ }^{1}$. Participants were then asked to retell the story they had just watched, giving as many details as possible and speaking directly into the computer microphone. Thus, each participant produced three oral stories which gave a total of forty-eight texts. Altogether the data for NS included 3,230 words and for NNS 3,290. In 2011 additional recordings were made of eight Cypriot subjects ( 3 males, 6 females), of the same age group and level of education as the first two groups. They were asked to retell the same three stories in Greek (2,877 words).

1 Some of the elicitation material can be consulted on http://www.youtube.com/watch?v= Y3p5ay1WchE (First aid). Unfortunately the other two videos (At the circus; The child's friend) have been withdrawn from the Web. A summary of the three stories is given in the appendix. 
The recorded performances were then transcribed, with an indication of features like syllable or pause length, where relevant. These details are important for the identification of autonomous RCs. The interviewer intervened the least possible, for example to help a NNS in difficulty because of a missing vocabulary item or to ask a participant to include an episode (s)he had overlooked. The NNS group was approximately at Level B2 on the Common European Framework of Reference scale.

\section{Frequency of Use of Relative Clauses}

Regarding the first research question, the following results were obtained (Table 1). In this table, all categories of RCs (see infra, Section 4) are grouped together.

Table 1.

Number of relative clauses used by NS and NNS

\begin{tabular}{|c|c|c|c|}
\hline Code & L1=French & Code & $\begin{array}{c}\text { L2=French } \\
\text { L1=Greek }\end{array}$ \\
\hline NS1 & 12 & NNS1 & 7 \\
\hline NS2 & 4 & NNS2 & 9 \\
\hline NS3 & 11 & NNS3 & 9 \\
\hline NS4 & 11 & NNS4 & 8 \\
\hline NS5 & 10 & NNS5 & 3 \\
\hline NS6 & 16 & NNS6 & 4 \\
\hline NS7 & 6 & NNS7 & 6 \\
\hline & & NNS8 & 5 \\
\hline Total & 70 & NNS9 & 10 \\
\hline Average & 10 & Total & 61 \\
\hline
\end{tabular}

We see that, on average, NNS use a smaller number of RCs than the NS. Actually, on the whole, NS use more subordinate clauses (including RCs) than NNS. This is not surprising in the light of research done on syntactic complexity in language acquisition. Studies on subordination in interlanguages draw attention to the "grammaticalization" of the language of learners (e.g. Klein \& Perdue 1992, 1997; Chini 1998; Giacalone Ramat 2000). Based on Givon's functionaltypological (1984/2001) or on Lehmann's typological model (1988), such studies hypothesize and show that in second language acquisition learners go through a context-bound pragmatic mode of expression which is predominantly paratactic, with minimal integration, towards modes of expression where subordination is increasingly present and is the sign of a stronger syntactic integration. 


\section{Frequency of Use of ParticularRPs Grammatical Functions}

In order to answer our second research question, we considered the RCs produced by the participants from a morphosyntactic point of view: we examined the RPs used and their grammatical functions in the embedded RC: qui ('who, which') for subject, que ('whom, which') for direct object, où ('where/ when, in which') for locational or temporal relations, the inflected form lequel for prepositional phrases (e.g. 'with whom/with which') (see Tables 2 and 3). The occurrences of ce qui (subject) and ce que (object), introducing RCs without NP antecedents (equivalents of which), have been combined for simplification, although ce qui is more frequent then ce que. Dont ('of which, whose') is absent from the data. Table 2 (NS) and Table 3 (NNS) show the distribution of RPs with their functions.

The oral narratives for both groups exhibit a very high frequency of qui pronouns and there does not seem to be much difference between the two groups. Aside from confirming the Keenan-Comrie (1977) hierarchy and the high accessibility of the subject to relativisation across languages, these results support other specific studies for spoken French, such as Gadet (2003) or Morel \& Danon-Boileau (1998).

Table 2.

Relative pronouns and their grammatical functions (NS)

\begin{tabular}{|l|c|c|c|c|c|c|}
\hline Code & $\begin{array}{c}\text { qui } \\
\text { subject }\end{array}$ & $\begin{array}{c}\text { que. direct } \\
\text { object }\end{array}$ & $\begin{array}{c}\text { où locative/ } \\
\text { temporal }\end{array}$ & $\begin{array}{c}\text { lequel in } \\
\text { PP }\end{array}$ & $\begin{array}{c}\text { ce qui/ } \\
\text { que }\end{array}$ & Total \\
\hline NS1 & 10 & - & 1 & - & 1 & 12 \\
\hline NS2 & 4 & - & - & - & - & 4 \\
\hline NS3 & 6 & 1 & - & 1 & 3 & 11 \\
\hline NS4 & 8 & - & 1 & - & 2 & 11 \\
\hline NS5 & 10 & - & - & - & - & 10 \\
\hline NS6 & 13 & - & 2 & - & 1 & 16 \\
\hline NS7 & 6 & - & - & - & - & 6 \\
\hline Total & 57 & 1 & 4 & 1 & 7 & 70 \\
\hline$\%$ & $81.5 \%$ & $1.4 \%$ & $5.7 \%$ & $1.4 \%$ & $10 \%$ & $100 \%$ \\
\hline
\end{tabular}


Table 3.

Relative pronouns and their grammatical functions (NNS)

\begin{tabular}{|l|c|c|c|c|c|c|}
\hline Code & $\begin{array}{c}q u i \\
\text { subject }\end{array}$ & $\begin{array}{c}\text { que. direct } \\
\text { object }\end{array}$ & $\begin{array}{c}\text { où locative/ } \\
\text { temporal }\end{array}$ & $\begin{array}{c}\text { lequel in } \\
\text { PP }\end{array}$ & $\begin{array}{c}\text { ce qui/ } \\
\text { que }\end{array}$ & Total \\
\hline NNS1 & 5 & - & - & 2 & - & 7 \\
\hline NNS2 & 8 & - & 1 & - & - & 9 \\
\hline NNS3 & 8 & - & - & - & 1 & 9 \\
\hline NNS4 & 4 & 4 & - & - & - & 8 \\
\hline NNS5 & 3 & - & - & - & - & 3 \\
\hline NNS6 & 3 & 1 & - & - & - & 4 \\
\hline NNS7 & 4 & - & 2 & - & - & 6 \\
\hline NNS8 & 4 & - & 1 & - & - & 5 \\
\hline NNS9 & 9 & - & - & 1 & - & 10 \\
\hline Total & 48 & 5 & 4 & 3 & 1 & 61 \\
\hline$\%$ & $78.7 \%$ & $8.2 \%$ & $6.5 \%$ & $5 \%$ & $1.6 \%$ & $100 \%$ \\
\hline
\end{tabular}

\section{Types of qui Relative Clauses}

Leaving aside the low frequency items (columns 3, 4, 5, 6), we now concentrate on the qui RCs found in the data. As it is well-known, RCs, although identical in form, may not function in the same way within a sentence. In our classification we adopt the traditional opposition between restrictive and non-restrictive (appositive) RC. ${ }^{2}$ We use de Vries (2006) and Morel \& Danon-Boileau (1998) descriptions of the behavior of non-restrictive $\mathrm{RCs}^{3}$ and create within the latter category subcategories that are adapted to the type of texts at hand (retelling oral narratives). All the examples are taken from our corpus.

2 We refer the reader to Kleiber (1987) for instance, for a discussion of the difficulties raised by this two-way classification and various proposals put forward to remedy them. But we consider that this distinction has enough validity for the purposes of this article.

3 Non-restrictive RCs (appositive) according to de Vries have the following properties, among others: they specify the whole antecedent, they can be deleted without a significant shift in meaning or loss of acceptability, they can follow other complements of the antecedent, they can be stacked asyndetically, they can be extraposed from their antecedent NP, they can have antecedents of any category (De Vries 2006: 21-32). Morel \& Danon-Boileau (1998: 53-58), referring only to spoken French use intonational patterns to classify relatives and their rhematic or non-rhematic function. So there are relatives that are integrated into the antecedent NP (restrictive or non-restrictive), while others are dissociated from their antecedent NP: they can be presentative, parenthetical or autonomous. 


\subsection{Restrictive Relative Clauses}

Since their property is to restrict the number of potential referents of an NP, they have an identification-referential function.

(1) l'homme qui était sur la terre [NNS2]

'the man who was lying on the ground' (as opposed to the others)

\subsection{Non-Restrictive Relative Clauses}

Non-restrictive RCs add a comment or a predication concerning the referent of the antecedent NP, without modifying its extension (see also footnote 3 ). In our data, there are three main types of qui non-restrictive relatives.

\subsubsection{The Canonical Variety, Often Called 'Explicatives' (or 'Appositives') in French Grammars}

The RC plays no role in the identification of the referent. It provides accessory information, a complementary description for instance.

(2) le magicien porte un chapeau qui est un peu bizarre. [NNS2]

'the magician wears a hat which is a bit strange.'

\subsubsection{Qui Clauses with a Predicative-Attributive Function: So- Called "Presentative" Sequences (c'est...qui, il y a...qui)}

It should be noted (see examples below) that French presentative RCs are often not translated with RCs in other languages. Presentative structures are discontinuous: "Presentative word + NP + qui" where the first part serves as a support for a predication on the referent (represented by the NP), the predication being performed by a RC. For example:

(3) [Incipit] Alors, c'est un monsieur qui est dans une voiture et le pneu de la voiture éclate. [NS1]

(So, it is a man who is in a car and the tire of the car blows out)

'So a man is in a car and the tire blows out.'

(4) Il y a une ambulance qui arrive. [NS2]

(There is an ambulance which/that is arriving)

'An ambulance arrives.' 
Semantically, presentation is an operation which determines the mode of existence (or the identity or the presence) of an object or a process. This existence is always more or less tightly linked to a localisation in place or time. The referent (see Lambrecht 1988) is cognitively non-accessible, nonidentifiable before being introduced into the structure. Once introduced it is promoted to a high degree of topicality, which makes it a potential topic/theme for the RC and other clauses that follow.

Two types of presentative structures (illustrated in (3) and (4)) are traditionally recognized in French, the c'est...qui ('it is...who/which') type and the il y a...qui ('there is...who/which') type.

In c'est...qui, ce is by nature deictic-anaphoric. Since the referent of the NP to be presented is not accessible, it cannot be textually anaphoric. It then functions as an anaphoric which presupposes the existence of the object/ person in a situation anterior to the present one. This is the case, in particular, at the very beginning of a text (as in the oral narratives considered here, see (3)). C'est can also be given a deictic reading: it is as if the referent existed under the eyes of the speaker (which is the case after viewing a video clip). Being deictic, c'est presupposes the presence of a speaker at the origin of the act of referencing.

Rather than asserting existence (as c'est), il y a posits the referent as an object/person which is going to play a role in the speech situation. It presents the referent in a more abstract, objective way than c'est; the speaker seems to be less involved. While il y $a$ introduces the new topic, its RC brings in new information which normally takes the form of an event related to the topic (see (4), the arrival of the ambulance) [for a discussion of these matters, see Lambrecht 1988].

\subsubsection{Qui Clauses with a Predicative-Attributive Function, Where the Antecedent is Governed by a Verb of Perception}

These RCs are always introduced by the subject RP qui.

(5) On entend les gens qui applaudissent. [NS2, NS7, NNS5]

(We hear the people who applaud)

'We hear people applauding/cheering.'

They are clearly predicative: Sentence (5) can be glossed as "I hear the people and they are cheering." Perception RCs always involve events. Since they depict perception in action, they are considered to be deictic (see Cadiot 1976; Furukawa 2005). 


\subsubsection{Qui Clauses with a Predicative-Attributive Function: the} So-Called "Autonomous" or "Narrative" Relative Clause

Sentences (6) and (7) are examples of such relatives:

(6) il les [=les ballons] donne à l'enfant // qui cette fois-ci accepte. [NS2]

'He gives them to the child, who this time accepts. [// indicates a pause]

(7) Là-dessus, il voit un marchand de ballons remplis de gaz là //qui volent d'hélium //qui marche. [NS3]

'Thereupon, he sees a man selling balloons, filled with gas, there, that fly, of helium... who is walking.'

Creissels (2004) notes that, with this type of construction, one refers to an event chronologically linked to a preceding event which is talked about in the phrasal unit to which the antecedent belongs. In other words, what is denoted is the succession of two events (See (6)). The RP behaves more like a coordinating element than a subordinating one: 'he gives them to the child... who this time accepts them (= and this time he accepts them)'.

Such RCs are rather independent from their antecedents, hence the term "autonomous" used by Morel \& Danon-Boileau and others to designate them. Morel \& Danon-Boileau (1998) and Kirchmeyer (2002) give a list of features which characterise this type of relatives. These can be summarized as follows: autonomous/narrative relatives are similar to independent utterances; they can be paraphrased with juxtaposed or coordinated constructions; they are often separated from their antecedent by several words or phrases; they are also marked by specific intonational contours and preceded by pauses; qui can be repeated and its final vowel elongated. (See example (7) as an illustration of these features.)

\section{Comparing the Use of Qui Relatives in NS and NNS Oral Narratives}

With the discussion in Section 5 in mind, we can now compare the uses of qui RCs in NS and NNS speech. Table 4 (NS) and Table 5 (NNS) give detailed information on the results, while Table 6 summarizes the main findings in a comparative fashion. 
Table 4.

Types of qui relatives used by NS

\begin{tabular}{|l|c|c|c|c|c|c|}
\hline Code & \multicolumn{5}{|c|}{ Non-restrictives } & Restrictives \\
\hline & Canonical & C'est...qui & Il y a...qui & $\begin{array}{c}\text { with perception } \\
\text { verbs }\end{array}$ & Autonomous & \\
\hline NS1 & - & 2 & 4 & 2 & 1 & 1 \\
\hline NS2 & - & 1 & 2 & - & 1 & - \\
\hline NS3 & - & - & - & 1 & 4 & 1 \\
\hline NS4 & 1 & 4 & 1 & - & 1 & 1 \\
\hline NS5 & 3 & - & 3 & - & 3 & 1 \\
\hline NS6 & 1 & - & 3 & 4 & 3 & 2 \\
\hline NS7 & - & 2 & 1 & 1 & 2 & - \\
\hline Total & 5 & 9 & 14 & 8 & $26.3 \%$ & $10.5 \%$ \\
\hline $\begin{array}{l}\% \\
57 \text { items }\end{array}$ & $8.8 \%$ & $15.9 \%$ & $24.5 \%$ & $14 \%$ & & $\begin{array}{c}\text { Restrictives } \\
6=10.5 \%\end{array}$ \\
\hline TOTAL & \multicolumn{7}{|c|}{ Non-restrictives $51=89.5 \%$} & & 6 \\
\hline
\end{tabular}

Table 5.

Types of qui relatives used by NNS

\begin{tabular}{|c|c|c|c|c|c|c|}
\hline \multirow[t]{2}{*}{ Code } & \multicolumn{5}{|c|}{ Non-restrictives } & \multirow[t]{2}{*}{ Restrictives } \\
\hline & Canonical & C'est...qui & Il ya...qui & $\begin{array}{c}\text { with perception } \\
\text { verbs }\end{array}$ & Autonomous & \\
\hline NNS1 & - & 4 & - & - & 1 & - \\
\hline NNS2 & 3 & 3 & - & - & 1 & 1 \\
\hline NNS3 & 5 & 2 & - & - & 1 & - \\
\hline NNS4 & 1 & 1 & 1 & 1 & - & - \\
\hline NNS5 & - & 2 & - & 1 & - & - \\
\hline NNS6 & - & 1 & - & - & - & 2 \\
\hline NNS7 & 2 & - & 1 & 1 & - & - \\
\hline NNS8 & - & - & 1 & 2 & - & 1 \\
\hline NNS9 & - & - & 2 & 6 & 1 & - \\
\hline Total & 11 & 13 & 5 & 11 & 4 & 4 \\
\hline $\begin{array}{l}\% \text { out of } \\
48 \text { items }\end{array}$ & $23 \%$ & $27 \%$ & $10.4 \%$ & $23 \%$ & $8.3 \%$ & $8.3 \%$ \\
\hline TOTAL & \multicolumn{5}{|c|}{ Non-restrictives $44=91.7 \%$} & $\begin{array}{c}\text { Restrictives } \\
4=8.3 \%\end{array}$ \\
\hline
\end{tabular}


Table 6.

Frequency of types of qui relatives - A comparison

\begin{tabular}{|l|l|l|l|}
\hline & & NS & NNS \\
\hline \multirow{4}{*}{ Non-restrictives } & Canonical & $8.8 \%$ & $23 \%$ \\
\cline { 2 - 4 } & C'est...qui & $15.9 \%$ & $27 \%$ \\
\cline { 2 - 4 } & Ily y...qui & $24.5 \%$ & $10.4 \%$ \\
\cline { 2 - 4 } & with perception verbs & $14 \%$ & $23 \%$ \\
\cline { 2 - 4 } & Autonomous & $26.3 \%$ & $8.3 \%$ \\
\hline Restrictives & & $10.5 \%$ & $8.3 \%$ \\
\hline
\end{tabular}

\section{Use of Qui Relatives by NS and NNS: Discussion}

We observe first that non-restrictive qui RCs are far more frequent than restrictive $\mathrm{RCs}$, in the narratives of both groups. The predicative function clearly dominates over the identificational function. This may be explained by the fact that the stories to be told by the participants did not necessitate precise identification of the protagonists, objects and places depicted, since interviewee and interviewer had both seen the cartoons and thus knew what the stories were about. The ratio might have been different with other types of oral genres, personal narratives for example.

Secondly the results indicate that both groups use the two types of presentational RCs (c'est...qui and il y a...qui) and the perception RCs, though not with the same frequency. NNS seem to prefer the c'est...qui and the perception relatives, and to not favor the il y a...qui relatives. A possible explanation could be, on the one hand, that French perception RCs have RC counterparts in Greek (see below, Section 8). As for the c'est...qui sequences, they are more frequent in French than the il y a...qui sequences, since they are widely used in contexts other than the presentational ones (for example: for identification, clefting, focussing (see Clech-Darbon et al., 1999: 84-88). NNS actually sometimes use c'est...qui presentational constructions where il y a...qui would be preferred by a NS.

Thirdly, the data indicate that NNS shy away from the use of narrative RCs. Kirchmeyer in her study of Swedish advanced learners (2002) obtained similar results. NNS appear to use relatives more confidently at the local level of the sentence, as in (2) for example (le magicien porte un chapeau qui est un peu bizarre, 'the magician is wearing a hat which is a little strange') where the canonical nonrestrictive relative is better integrated into the NP. On the contrary, a sentence like (7) [produced by a NS], where the RC escapes the scope of the NP requires boldness and dexterity, which NNS, although advanced, do not seem to have yet. 


\section{Greek>French Cross-Linguistic Influence?}

We hypothesised that the learners' native language and its discourse structures could have some influence on their oral narrations in the target language. To ascertain this, the narratives (in Greek) of the eight Cypriots who participated in the second part of the experiment were examined with respect to relativisation. ${ }^{4}$

The most significant results are the following:

i) Each Cypriot speaker [CS] used an average of 7,9 RCs, as compared to the French NS group (10) and the NNS group (6.7). The learners' speech in French is therefore less complex (see section 3 ) than it would probably be in their own language.

ii) The relativiser ${ }^{5}$ was overwhelmingly found in subject function $(73 \%$ of occurrences), a figure comparable to those for the NS and NNS groups (81.5\% and $78.7 \%$, respectively - See Table 1 ).

iii) However, examination of the discursive functions of the RCs with subject relativisers revealed important differences between French (NS), interlanguage French (NNS) and Greek (CS). Table 7 presents the results which will be commented upon. Within the limits of this article, we will concentrate on three points: the presentative structures, the perception verbs and the autonomous RCs.

Table 7.

Types of RCs with a subject relativiser, used by Cypriots (in Greek)

\begin{tabular}{|c|c|c|c|c|c|c|c|}
\hline \multirow[t]{2}{*}{ Code } & \multicolumn{6}{|c|}{ Non- restrictives } & \multirow[t]{2}{*}{ Restrictives } \\
\hline & Canonical & $\begin{array}{c}\text { Ine... pou } \\
\text { ('it is... who } \\
\text { /which') }\end{array}$ & $\begin{array}{c}\text { Iparki... } \\
\text { pou ('there } \\
\text { is... who / } \\
\text { which') }\end{array}$ & $\begin{array}{l}\text { with } \\
\text { appearing } \\
\text { verbs }\end{array}$ & $\begin{array}{c}\text { with } \\
\text { percept. } \\
\text { verbs }\end{array}$ & Autonomous & \\
\hline CS1 & 2 & - & - & 1 & - & - & 2 \\
\hline CS2 & - & 2 & - & 1 & - & - & 1 \\
\hline CS3 & 5 & - & - & 1 & 1 & - & - \\
\hline CS4 & - & - & - & 1 & - & 1 & 2 \\
\hline CS5 & 1 & - & 1 & - & 1 & - & 2 \\
\hline CS6 & 2 & - & - & 1 & 3 & 4 & 6 \\
\hline CS7 & - & - & - & - & 2 & - & 1 \\
\hline CS8 & 1 & - & - & - & 1 & - & - \\
\hline $\begin{array}{l}\text { Total: } \\
46\end{array}$ & 11 & 2 & 1 & 5 & 8 & 5 & 14 \\
\hline \multirow[t]{2}{*}{$\begin{array}{l}\% \text { out } \\
\text { of } 46\end{array}$} & $24 \%$ & $4.5 \%$ & $2 \%$ & $10.75 \%$ & $17.5 \%$ & $10.75 \%$ & $30.5 \%$ \\
\hline & \multicolumn{6}{|c|}{ Non-restrictives $32=69.5 \%$} & $\begin{array}{l}\text { Restrictives } \\
14=30.5 \%\end{array}$ \\
\hline
\end{tabular}

$\mathbf{4}$ The recordings revealed a number of interesting differences in French NS and Greek NS narratives, which would need to be studied further.

$\mathbf{5}$ We choose the term 'relativiser' here to cover both pou (relativiser-complementizer) and o opios (relative pronoun) found in participants' narratives. 
1) There are equivalents in Greek for c'est...qui and il y a...qui ('ine...pou/o opios' and 'iparxi...pou/o opios' respectively), but they are underused by CS as Table 7 shows, in comparison with another type of presentational structure, illustrated in (8).

(8) Emfanizete sto parko kapios o opios poula balonia. [CS3]

'Appears in the park someone who sells balloons.'

These verb-first sentences which feature a small set of intransitive "appearing" verbs (emfanizome, 'appear'; erxome 'come'; parousiazome, 'present oneself') often announce unpredictable information (Holton et al. 1997: 428). They are used to avoid having in initial position of the sentence (as theme) an indefinite NP, i.e. an NP whose referent is unidentifiable by the hearer (see Lambrecht 1988: 147-149). Such constructions are rare in French and typical of the formal language. For these reasons, the Greek "appearing" RCs do not interfere in the oral French of advanced learners, who have integrated in their interlanguage the French presentational structures.

2) We saw above (Tables 4 and 5) that, compared to NS, NNS used more perception verb RCs than NS (23\% vs $14 \%)$. This seemingly important difference may be due to cross-linguistic influence. Table 8 shows that perception verb RCs represent $17.5 \%$ of the RCs with a "subject" relativiser in CS data. In CS' narratives, vlepo ('see') in the first person, singular or plural [and more marginally akouo 'to hear'] is frequent at the incipit of a narrative, or within the body of the retold story, to introduce a new protagonist. Actually, the presence of presentational vlepo in the CS narratives is heightened by the fact it can be accompanied by an "infinitive" clause, in addition to a RC. ${ }^{6}$ Example (9) illustrates this construction.

(9) Vlepi kapion kirio na perna me balonia. [CS9]

'he sees a man passing by with ballons.' [na perna = 'infinitive' marker na + verb $3^{\text {rd }}$ pers. present].

The two structures -perception RCs and perception na-clauses-appear therefore to be favorite constructions in Greek to convey the simultaneity of two events, with a mediating verb which expresses a visual mode of contact. There may therefore be a propensity for NNS to overuse the parallel French perception RC.

6 For a complete list of perception verbs, see Klairis \& Babiniotis 2010: 570. 
3) Autonomous relatives are almost absent in CS narratives. In our data, RCs in the Greek texts are much more closely integrated into their antecedent NPs than in French. This may help to understand the low number of such RCs in NNS narratives.

\section{Conclusion}

The analysis of our data revealed a number of similarities between NS and advanced NNS narratives. a) For the two groups, the ratio of non-restrictive RCs to that of restrictive RCs is high, as is the ratio of RCs introduced by qui as compared to other RPs. b) NNS seem to control rather well the use of the French presentative RCs, which are considered to be 'gallicisms', i.e. very specific to French, and may not be readily acquired by learners. Like NS, they make use of these theme-rheme structures in the introduction of their narratives (Alors, c'est un monsieur qui est dans une voiture [Example (3)]), to set up the scene and present the protagonists, or they use them to introduce new episodes as "continuative" RCs (Il y a une ambulance qui arrive [Example (4)]). They have thus mastered rather well these text cohesion devices, with the reservation that they do not favour the il y a...qui presentative sequences.

There are however differences between the two groups.

a) If subordination is taken as an index of complexity, NNS' texts are less complex than NS' texts.

b) Possibly under the influence of Greek narrative discourse characteristics, NNS use more predicative perception RCs than NS.

c) Within the qui clauses group, NNS -more than NS- have recourse to the regular, canonical non-restrictive RCs that serve to give complementary information about properties of the antecedent/referent (descriptions, for example). Such descriptive RCs (like the restrictive RCs) tend to be integrated into, dependent upon, the antecedent NP, at the local micro-syntactic sentential level. This result is consistent with Hankock \& Kirchmeyer's study (2002) of advanced Swedish learners' narrative competence (see also Bartning \& Kirchmeyer 2003; Bartning \& Schlyter 2004). In the case of Cypriot learners, this tendency may also be explained by syntactic-discursive features in their native language.

Autonomous RCs are significantly more frequent in NS narratives. It seems therefore that NS, as compared to NNS, focus less on the local organization of sentences, and more on the overall discursive organization of the oral texts they produce. The use of less canonical RCs, dissociated from their antecedents, and of il y a...qui presentative constructions can thus be considered to be, in French, a characteristic of NS and very advanced learner/ user narrative competence. 


\section{References}

Bartning, I. and N. Kirchmeyer. 2003. Le développement de la compétence textuelle à travers les stades acquisitionnels en français L2. Acquisition et Interaction en Langue Etrangère 19: 9-39.

Bartning, I. \& S. Schlyter. 2004. Itinéraires acquisitionnels et stades de développement en français L2. French Language Studies 14: 281-299.

Cadiot, P. 1976. Relatives et infinitives «déictiques» en français. DRLAV 13: 1-64.

Chini, M. 1998. La subordinazione in testi narrativi di apprendenti tedescofoni: forma e funzione. Linguistica e Filologia 7: 121-157.

Clech-Darbon, A., G. Rebuschi and A. Rialland. 1999. Are there cleft sentences in French? In G. Rebuschi and L. Tuller, The Grammar of Focus. Amsterdam: John Benjamins, 83-118.

Creissels, D. 2004. Cours de syntaxe de sciences du langage, Université Lyon 2. http://www.infotheque.info/cache/8875/lesla.univ-lyon2.fr/article. php3\%3fid_article=562.html Retrieved 29 September 2011.

Furukawa, N. 2005. Pour une sémantique des constructions grammaticales. Thème et thématicité. Bruxelles: De Boeck-Duculot.

Gadet, F. 2003. La relative française, difficile et complexe. In S. Kriegel (ed.), Grammaticalisation et réanalyse - Approches de la variation créole et française. Paris: CNRS Éditions, 251-268.

Giacalone Ramat, A. 2000. Typological considerations on second language acquisition. Studia Linguistica 54(2): 123-135. 
Givón, T. 2001. Syntax - A Functional-typological Introduction. Amsterdam: John Benjamins. [first ed. 1984]

Hancock, V. 2002. L'emploi des constructions en c'est $x$ qui/que en français parlé: une comparaison entre apprenants de français et locuteurs natifs. Proceedings of the XV Skandinaviske romanitkongress, Romansk Forum 16: 379-388.

Hancock, V. and N. Kirchmeyer. 2002. À la recherche des traits d'une organisation discursive avancée en français $L 2$. La relative aux micro- et macro-niveaux dans un corpus d'apprenants. L'Information grammaticale 93: 3-9.

Holton, D., P. Mackridge and I. Philippaki-Warburton. 1997. Greek:A Comprehensive Grammar of the Modern Greek Language. London: Routledge.

Keenan, E. and B. Comrie. 1977. Noun phrase accessibility and universal grammar. Linguistic Inquiry 8(1): 63-99.

Kirchmeyer, N. 2002. Étude de la compétence textuelle des lectes d'apprenants avancés. Aspects structurels, fonctionnels et informationnels. Doctoral thesis, Forskningsrapporter 17, Institutionen för franska italienska och klassiska språk, Stockholms Universitet.

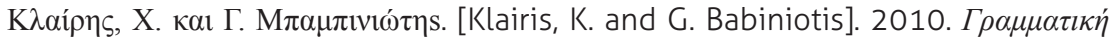

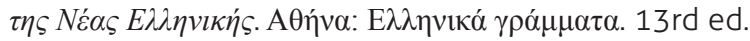

Kleiber, G. 1987. Relatives restrictives/relatives appositives: dépassement(s) autorisé(s). Langages 88: 41-63.

Klein, W. \& C. Perdue. 1992. Utterance Structure. Developing Grammars Again. Amsterdam: John Benjamins.

Klein, W. \& C. Perdue. 1997. The basic variety (or: Couldn't natural languages be much simpler ?). Second Language Research 13(4) : 310-347.

Kounouni, M. 2010. Le récit oral en L1 et L2: Étude particulière de la connectivité de 'donc'. MA. thesis, University of Cyprus.

Lambrecht, K. 1988. Presentational cleft constructions in spoken French. In J. Haiman and S.A. Thompson (eds.), Clause Combining in Grammar and Discourse. Amsterdam: John Benjamins, 135-180. 
Lehmann, C. 1988. Toward a typology of clause linkage. In J. Haiman and S.A. Thompson (eds), Clause Combining in Grammar and Discourse. Amsterdam: Benjamins, 181-225.

Monville-Burston, M. 2008. Évaluer la compétence par un test de jugement de grammaticalité: le cas de la relativisation chez des apprenants chypriotes hellénophones avancés en FLE. In J. Durand, B. Habert $\&$ B. Laks (eds.) Congrès Mondial de Linguistique Française(Paris 9-12 juillet), Paris: Institut de Linguistique Française. CD-Rom, 1779-1791.

Monville-Burston, M. \& F. Kakoyianni-Doa. 2009. Aspects of the interlanguage of advanced Greek-speaking Cypriot learners of French: Relative clauses. In E. Labeau \& F. Myles (eds.), The Advanced Learner Variety: The Case of French. Bern: Peter Lang, 142-170.

Monville-Burston, M. \& M. Kounouni. 2008. Introspection et pédagogie : Que disent les apprenants sur la relativisation? In J. Burston, E. Gabriel, M. MonvilleBurston \& P. Pavlou (eds.), Languages for Intercultural Dialogue. Nicosia: The European Parliament Office in Cyprus and the Ministry of Education and Culture of the Republic of Cyprus, 103-118.

Monville-Burston, M. \& M. Kounouni. 2010. Deux procédures expérimentales pour tester la relativisation dans l'interlangue d'apprenants chypriotes hellénophones en FLE. In A. Psaltou-Joycey and M. Mattheoudakis (eds.), Advances in research on language acquisition and teaching. Selected papers. Actes du $14^{\text {ème }}$ Colloque International de l'Association Grecque de Linguistique Appliquée (14-16 déc. 2007).

Morel, M.-A. and L. Danon-Boileau. 1998. Grammaire de l'intonation. L'exemple du français oral. Paris: Ophrys.

de Vries, M. 2006. The syntax of appositive relativisation: On specifying coordination, false free relatives, and promotion. Linguistic Inquiry 37: 229-270. 


\section{Appendix}

\section{Summary of the three Mordillo cartoons to be narrated}

\section{First aid}

Along a country road, a man is driving a car that does not seem to be running very well. He finally crashes into a tree. An ambulance arrives at once. Three male nurses come out. Two of them load the wrecked car onto a stretcher while the third one puts bandages on the tree. The ambulance departs, leaving the stunned driver on the road.

\section{At the circus}

The scene shows a circus performer throwing knives around his partner, a woman, who is backed by a wooden panel. You can hear the audience applaud. Then the woman ties a headband around the artist's eyes: it is the second part of the performance. Then we can hear the woman's footsteps and we assume she is leaving the stage. But we see her hidden behind the panel. After having thrown all his knives, the man takes off his headband among the whistles and applause of the audience. We discover then that his partner had resumed her initial position between the blades.

\section{The child's friend}

The scene takes place in a park. A woman is sitting on a bench watching her child playing in a sandbox. A man arrives, greets the woman and sits beside her. The child does not like this man. When he addresses his mother the child responds by giving him a big kick in the leg. The man does not lose his cool and tries to coax the child by giving him a candy. The child then bites his finger and throws sand into his eyes. Then along comes a balloon seller. The man has an idea and rushes towards him. He returns with all the balloons and promptly offers them to the child, who accepts them. The child, who is lighter than the balloons, leaves the ground and slowly disappears into the air. The man having gotten rid of the child is finally alone with the woman whom he kisses on the cheek. 
Major Trends in Theoretical and Applied Linguistics 